\title{
Perkawinan Lintas Agama dalam Kajian Tafsir Formatif
}

\author{
M. Mu'allim ${ }^{1}$
}

\begin{abstract}
This article discusses the issue of interreligious mariage in the formative era of Islam. It discusses the different opinions found in the time of the Prophet Muhammad, his Companions and his Followers.

The primary sources of this article are the books of Hadith, the classical tafsirs which record the interpretation of the Qur'an in the Formative Period, and the book of history, such as Tabari's Tärikh.

This article concludes that there are two opinions in terms of interreligious marriage: those who opine the permissibility and those who opine the impermisibility.
\end{abstract}

Keywords: ahl al-kitāb, mushrikāt, banū Isrā'ìl .

\section{Pendahuluan}

Dalam Islam, perkawinan merupakan salah satu bentuk perbuatan sosial yang juga menjadi bagian dari ajaran agama. Ini terbukti dengan banyaknya ayat al-Qur'ān dan hadith nabi Muhammad saw yang menjelaskan tentang perkawinan. Bahkan beliau saw memberi tuntunan dan contoh konkrit perihal tersebut, yang tentunya (semua itu) untuk menunjukkan tata cara dan aturanaturan yang seharusnya diikuti oleh umat Islam.

Namun lain persoalannya, ketika perkawinan dihadapkan pada kasus perbedaan agama, yang selalu memunculkan perdebatan pada setiap masa. Ia (perkawinan lintas agama) merupakan kasus klasik yang selalu muncul dengan berbagai wacana dan perdebatan di dalamnya, khususnya bagi umat Islam, bahkan sampai saat ini. Perdebatan tersebut belum juga terselesaikan, kendati dalam sejarah umat Islam telah ditemukan banyak kasus perkawinan lintas agama, sebagaimana tertuang dalam berbagai riwayat/transmisi yang ada.

Riwayat-riwayat tersebut tidak lain merupakan kumpulan data historis yang dapat ditafsirkan dalam berbagai pengertian bahkan yang bertentangan sekalipun. Apalagi ketika riwayat-riwayat tersebut dipahami oleh berbagai

${ }^{1}$ Dosen Fak. Syariah, IAIN Ambon. Alamat: Jl. Dr. H. Tarmizi Taher, Kebun Cengkeh, Batu Merah Atas, Ambon, 97128. E-mail: mualeem@gmail.com / mmualeem@yahoo.com. 
komunitas akademik dengan kapasitas keilmuan dan latar belakang yang berbeda. Dengan demikian, perdebatan hampir dapat dipastikan akan semakin meluas seiring dengan perkembangan pemikiran manusia. Kenyataan ini dapat dilihat dari penafsiran yang beragam tentang ayat-ayat al-Qur'ān, berkaitan dengan perkawinan lintas agama. Sehingga, yang harus ditemukan adalah akar persoalan yang menyebabkan perbedaan pendapat tersebut.

Tulisan ini untuk mencari solusi dari perdebatan di atas, atau paling tidak diharapkan dapat meminimalisir perbedaan pendapat yang selama ini terjadi, sehingga didapatkan suatu pola pemetaan pendapat yang mudah dipahami, karena ia digali dari akar persoalan yang melatar belakanginya.

Deretan penafsiran dari masa ke masa tidaklah terhitung jumlahnya, oleh karena itu penulis membedakannya berdasarkan tiga periodisasi kemunculannya, yaitu: tafsir formatif, tafsir klasik dan tafsir modern/kontemporer. $^{2}$

Sebagai upaya penafsiran tertua, tafsir formatif disinyalir telah menjadi embrio kemunculan tafsir-tafasir yang datang berikutnya, bahkan ia dijadikan rujukan bagi para mufassir, baik klasik maupun modern/kontemporer. Dan berdasarkan alasan inilah, penulis bermakud membahas tema (perkawinan lintas agama) di atas, dalam tinjauan tafsir formatif.

\section{Respon Rasulullah saw terhadap Kasus Perkawinan Lintas Agama}

Masa Rasulullah setidaknya dapat dibedakan menjadi dua periode; Mekah dan Madinah. Periode Mekah merupakan masa penanaman dasar-dasar akidah Islam, sehingga ayat-ayat yang tergolong Makiyah tidak banyak berbicara tentang aturan hukum ataupun tatanan kehidupan sosial yang dicitacita Islam, sebagaimana tergambar pada ayat-ayat Madaniyah, yang turun

${ }^{2}$ Dalam hal ini, penulis akan menggunakan pembedaan dan pemetaan berdasarkan klasifikasi tafsir, yang terdiri dari: (1) Tafsir Formatif, yaitu upaya penafsiran awal yang dimulai sejak masa Rasulullah saw, sahabat, dan tabi'i, sampai datangnya masa tafsir klasik. Penafsiran pada masa ini tidak ada yang sampai pada generasi sekarang dalam bentuknya yang utuh, kecuali berupa riwayat-riwayat yang tersebar di sekian banyak kitab tafsir klasik, yang datang selanjutnya. (2) Tafsir Klasik, adalah upaya penafsiran yang dilakukan oleh para ulama pada generasi selanjutnya. Masa ini dimulai sejak diketemukannya literatur klasik (tafsir al-Qur'ān) secara utuh, yakni tafsir al-Ṭabari. Beberapa penulis menyatakan bahwa, Tafsir al-Ṭabari merupakan karya tafsir tertua (generasi abad-4). Lihat, Muḥammad 'Abd al-'Ázịm al-Zarqānī, Manāhil al-'Irfān fì 'Ulūm al-Qur'ān, Jilid II (Beirut: Dār al-Kutub al-'Ilmì, 1996), 33. Lihat juga: Thameem Ushama, Methodologhies of The Qur'anic Exegesis (Kuala Lumpur: A.S. Noordeen, 1995), 86. (3) Tafsir Modern/ Kontemporer, yaitu beberapa upaya penafsiran dalam literatur tafsir, yang lahir sejak terjadinya modernisasi Barat dan diikuti gerakan pembaharuan dalam Islam oleh beberapa tokoh terutama di Timur Tengah, sampai sekarang. 
setelahnya. ${ }^{3}$ Dengan demikian, perhatian beliau sama sekali belum tertuju pada pengambilan sikap atas kasus-kasus perkawinan lintas agama yang terjadi pada saat itu. Bahkan ketika di Mekah, beliau sempat menikahkan putri beliau "Zainab" dengan seorang musyrik, Abū al-'Āṣs ibn al-Rabī' 4

Keadaan ini berlanjut sampai datang masa hijrah ke Madinah, yakni ketika sudah terdapat pemisahan yang jelas antara para pengikut nabi saw dan orang-orang kafir Quraisy, baik secara geografis maupun sosial. ${ }^{5}$ Dan pada saat itulah mulai terjadi beberapa kali kontak senjata antara kedua kelompok tersebut di beberapa tempat sekitar Mekah-Madinah. Hingga pada suatu hari, terjadilah kasus Marthad ibn Abī Marthad yang bermaksud meminta izin kepada Rasul untuk mengawini Anāq, seorang pelacur musyrikah Arab, akan tetapi beliau melarangnya. ${ }^{6}$ Namun tidak diketahui apakah pelarangan tersebut karena adanya unsur syirik ataukah ketuna-kesusilaan yang ada pada diri wanita tersebut. Beberapa riwayat memberi indikasi bahwa setelah kejadian tersebut turun Q.S. al-Nūr [24]: 3, yang memberikan indikasi bahwa pelarangan tersebut bukan karena syirik melainkan unsur zina. ${ }^{7}$ Jika demikian adanya, dapat diduga

${ }^{3}$ Lihat: Wael B. Hallaq, The Origins and Evolution of Islämic Law, Cet. I (Cambridge: University Press, 2005), 19. Hal ini, jelas berbeda dengan beberapa tahun berikutnya, di mana telah terbentuk suatu komunitas masyarakat muslim (ummah) di Madinah. Sehingga, beberapa kasus dapat diputuskan berdasarkan ijtihad dan wahyu,

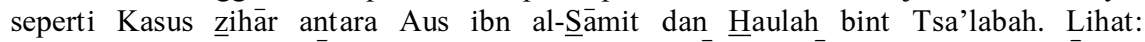
Muhammad ibn Ismā'ìl Abụ 'Abdillāh al-Bukhāri al-Ju'fī, al-Jāmi' al-Sahịh alMukhtașar, Juz. IV, Cet. III (Beirut: Dār Ibn Kathīr, al-Yamāmah, 1987), 1851. Lihat

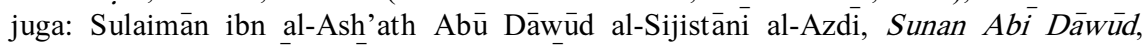
Muhaqqiq: M. Muhyyi al-Dīn Abd al-Ḥamīd, Juz. I (Beirut: Dār al-Fikr, tt), 674. Juga beberapa kasus lain, seperti pencuarian, perzinahan dan sebagainya.

${ }^{4}$ Selengkapnya lihat: Abū 'Abdillāh Muhammad ibn Aḥmad ibn Abū Bakr ibn Faraj al-Qurțūbì, al-Jāmi ' li Aḥkām al-Qur’ān, Juz. XVIII, Cet. II (Kairo: Dār al-Sha‘b, 1372), 55.

${ }^{5}$ Lihat: Wael B. Hallaq, A History of Islamic Legal Theories, an introduction to sunni ușūl al-fiqh (Cambridge: Cambridge University Press, 1997), 4. Lihat juga: Akram Diyà' al-'Umari, Madinah Society at the Time of the Prophet, translated from alMujtama' al-Madāni fí al-Nubuwwah, by Huda Khațāab, edisi. II (Virginia USA: the International Institute of Islamic Thought, 1995), 51.

${ }^{6}$ Peristiwa itu terjadi ketika Marthad menyusup ke Mekah demi melaksanakan janjinya untuk membebaskan temannya yang ditawan orang-orang kafir. Lihat: Abū Ja'far Muhammad ibn Jarir al-Ṭabari, Tärikh al-Umam wa al-Muluk, Juz. II, Cet. I (Beirut: Dä̀r al-Kutub al-'Ilmiyah, 1407), 213. Lihat juga: Muhammad ibn 'İsā Abū 'İsā

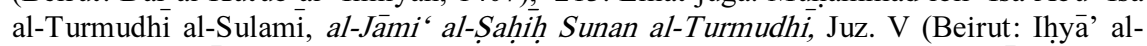
Turāth al-'Arabì, tt), 328. Lihat juga Abū Bakr Ahmad ibn al-Husain ibn 'Ali ibn Mūsā al-Baihaqìi, Sunan al-Baihaqī al-Kubrā, Juz. VII (Makkah al-Mukarramah: Maktabah Dār al-Bāz, 1994), 153, No. Hds. 13639.

${ }^{7}$ Ayat tersebut menjelaskan tentang larangan perkawinan antara pezinah dengan orang-orang yang terjaga, "Laki-laki yang berzina tidak mengawini melainkan perempuan yang berzina, atau perempuan yang musyrik, dan perempuan yang berzina tidak dikawini melainkan oleh laki-laki yang berzina atau lelaki yang musyrik, dan yang 
bahwa pada masa-masa awal periode Madinah belum terdapat aturan yang jelas tantang perkawinan lintas agama.

Pada masa awal-awal hijrah, turun juga Q.S. 2: 221, yang menjelaskan tentang larangan menjalin hubungan perkawinan dengan orang-orang musyrik, baik lelaki maupun perempuan. Dan sebagaimana diketahui bahwa surah alBaqarah adalah surah pertama yang turun di Madinah. Namun tidak ada suatu keterangan yang menjelaskan tentang manakah yang lebih dulu dari kedua ayat tersebut (Q.S. 24: 3, dan 2: 221). Jika dilihat dari urutan turunnya surah, maka surah al-Baqarah lebih dulu dari pada al-Nūr. Akan tetapi permasalahannya adalah, tidak semua ayat dalam suatu surah turun sekaligus bersama-sama. Oleh karenanya, belum tentu Q.S. 2. 221 turun lebih dulu dibandingkan Q.S. 24: 3 tersebut. $^{8}$

Namun, ketika kita menilik kembali riwayat di atas, seakan-akan Q.S. 24: 3 turun lebih dulu daripada Q.S. 2: 221. Karena jika tidak demikian, Marthad tidak mungkin meminta izin untuk mengawini 'Anāq yang jelas-jelas masih menyembah berhala. Demikian juga, kendati nabi melarangnya, namun beliau sama sekali tidak memberikan alasan yang jelas tentang pelarangan tersebut kepada Marthad hingga turun Q.S. 24: 3. ${ }^{9}$ Jika melihat beberapa indikasi di atas, riwayat al-Turmudhi dapat dijadikan landasan untuk menyatakan bahwa Q.S. 24: 3 turun turun lebih dulu daripada Q.S. 2: 221, walaupun untuk selanjutnya kedua ayat tersebut sama-sama diberlakukan.

demikian itu diharamkan atas orang-orang yang mu'min". Dalam riwayatnya, alTurmudhi menyebutkan bahwa Rasulullah saw berkata pada Marthad ra: "Wahai Marthad, Laki-laki yang berzina tidak (boleh) mengawini melainkan perempuan yang berzina, atau perempuan yang musyrik, dan perempuan yang berzina tidak (berhak) dikawini melainkan oleh laki-laki yang berzina atau lelaki yang musyrik, maka janganlah engkau menikahinya!". Selengkapnya, lihat Muhammad ibn 'Isā Abū 'İsā al-Turmudhi

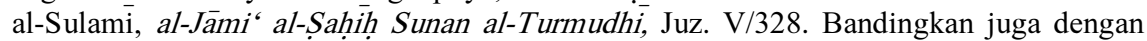
Ahmad ibn Shu'aib Abū Abd al-Raḥmān al-Nasā', $\overline{\dot{i}}$, al-Mujtabā min al-Sunan, Muhaqqiq: Abd al-Fattāh Abū al-Ghadah, Juz. VI, Cet. II (Halb: Maktabah al-Maṭbù'àt al-Islāmiyah, 1986), 66.

${ }^{8}$ Tapi bagaimanapun, kasus Marthad ra tersebut berlangsung sebelum akhir tahun 3 H, karena pada bulan Șafar 3 H, ia meninggal. Dalam hal ini, Muhammad Ibn Sa'd menyebutkan dalam kitabnya al-Tabaqāt al-Kubrā bahwa, Marthad meninggal bersama 9 orang sahabat lainnya, dalam penyergapan yang dilakukan oleh orang-orang kafir ketika ia menjalankan tugas mengajarkan al-Qur'an di luar Madinah. Lihat Muhammad Ibn Sa'd ibn Manì' al-Hāshimī al-Bașrī, al-Ṭabaqāt al-Kubrā, Juz. I, Cet. II (Beirut: Dār alKutub al-'Ilmiyah, 1997), 42.

${ }^{9}$ Lihat kembali Muhammad ibn 'Īsā Abū 'Īsā al-Turmudhì al-Sulamī, al-Jâmi' al-Sahịh Sunan al-Turmudhì, Juz. V/ 328, No. Hds. 3177. Lihat juga Abū Bakr Ahmad ibn al-Ḥusain ibn 'Alì ibn Mūsā al-Baihaqì Sunan al-Baihaqi al-Kubra: VII/153, No. Hds. 13639. Dan juga Aḥmad ibn Shu'aib Abū Abd al-Raḥmān al-Nasāà', al-Mujtabā min al-Sunan, Juz. VI/66. 
Pada tahun 6 hijriyah, Rasulullah saw bersama para sahabat bermaksud melakukan 'umrah, namun dihalangi oleh orang-orang Quraisy di Hudaibiyah, maka terjadilah perjanjian Hudaibiyah yang disusul Bai'ah al-Rị̣wān. Dalam peristiwa tersebut turun beberapa ayat al-Qur'ān, termasuk Q.S. 60: 10, yang di dalamnya terdapat redaksi wa lā tumsikū bi 'ịam al-kawāfir, yakni larangan mempertahankan perkawinan dengan orang-orang kafir. Turunnya ayat ini langsung mendapat respon positif dari kaum muslimin. Oleh karenanya, para sahabat, termasuk 'Umar ibn al-Khațtāa ra dan Ṭalhah ibn 'Ubaidillah ra yang pada saat itu masih mempunyai istri-istri kafir segera menceraikan mereka demi mengamalkan materi ayat tersebut. ${ }^{10}$

Dalam hal ini, penulis tidak menemukan satupun redaksi hadith qauli, yang secara langsung mengungkapkan sabda Rasul perihal turunnya Q.S. 60: 10 ini. Mungkin saja, beliau mengganggap hal itu tidak perlu dilakukan karena sudah ada naș șarị yang langsung dapat dipahami serta diamalkan oleh para sahabat pada saat itu juga. Dan, dua tahun kemudian, tepatnya pada bulan Ramaḍān tahun 8 hijriyah, terjadilah peristiwa besar sebagaimana terukir dalam sejarah, yaitu penaklukan kota Mekah, yang lazim disebut fath Makkah.

Setelah peristiwa itu turunlah beberapa ayat, termasuk di dalamnya Q.S. al-Maidah [5]: 5, yang memuat penjelasan tentang kebolehan mengawini para wanita ahl al-kitāb dengan kriteria "al-Muḥsanät'. Sebagaimana dijelaskan Ibn 'Abbās ra, bahwa setelah Q.S. 2: 221 turun, para sahabat mencegah dari bentuk perkawinan tersebut. Maka setelah turun Q.S. 5: 5, mereka sama menikahi wanita ahl al-kitāb. ${ }^{11}$

Dari pemaparan di atas jelaslah bahwa, selama periode Mekah, nabi saw sama sekali tidak menunjukkan respon terhadap kasus-kasus perkawinan lintas agama. Dan hal itu baru dilakukan setelah beliau dan para pengikutnya hijrah ke

${ }^{10}$ 'Umar ibn Khatțāb menceraikan dua istrinya sekaligus; yaitu (1) putrinya Abū Umaiyyah ibn Mughïrah yang akhirnya dikawini oleh Mu'āwiyah ibn Abū Sufyān (2) Ummu Kalthūm bint Jazūl al-Khazā'iyyah, ibu dari 'Abdullāh ibn 'Umar ra, yang akhirnya dikawini oleh Abū Jaḥm ibn Hudhāfah ibn Ghānim. Demikian juga dengan Ṭalhah ibn 'Ubaidillah ra ibn 'Uthmān ibn 'Amr al Taimi, ia menceraikan istrinya bernama Urwā bint Rabi' ah ibn Hārith ibn Abd al-Muṭallib. Namun setelah mantan istrinya tersebut masuk Islam, iapun dikawin oleh Khalid ibn Sa'id ibn 'Āṣs. Dua sahabat di atas adalah dua dari sekian banyak sahabat yang menceraikan istri-istrinya setelah turun Q.S. 60: 10 tersebut. Selengkapnya lihat Muhammad ibn Jarir ibn Yazid ibn Khālid Abū Ja'far al-Ṭabarì, Jāmi' al-Bayān 'An Ta'wì Àyi al-Qur'ān, Juz. XII (Beirut: Dār al Fikr, 1405 H), 68, 70. Lihat juga: Abū al-Qāsim Sulaimān ibn Ahmad ibn Ayyūb al-Ṭabrāni, al-Mu'jam al-Kabīr, Juz. XX, Cet. II (Mūṣal: Maktabah al-'Ulūm wa alHikam, 1983), 9.

${ }^{11}$ Lihat Abu al-Qāsim Sulaimān ibn Aḥmad ibn Ayyūb al-Ṭabrānī, al-Mu'jam alKabir, Juz. XII/105. Pendapat ini diikuti oleh beberapa tabi ‘̄in, termasuk: Mujāhid, Sa ${ }^{\circ} \overline{i d}$ ibn Jubair, Ikrimah, dll. Lihat Abū al-Fidā' Ismā'‘̄il ibn 'Umar ibn Kathīir al-Qurashī alDimashqìi, Tafsìir al-Qur'ān al-'Ażìm, Juz. I (Beirut: Dār al-Fikr, 1401 H), 347. 
Madinah, memusatkan kegiatan dakwah, ekonomi, serta membentuk dan membenahi tatanan sosial yang ada di sana. ${ }^{12}$

Walaupun demikian, respon yang beliau tunjukkan sama sekali tidak tampak muncul dari inisiatif pribadi, melainkan perintah dan ketetapan wahyu. Hal ini dapat dilihat dari sikap pasif beliau atas kasus-kasus perkawinan lintas agama yang terjadi di kalangan para sahabat, sebelum turunnya wahyu. Sedangkan setelah wahyu turun, para sahabat langsung mengamalkan żāhir alnaș, sehingga beliau tidak banyak berkomentar dalam hal ini. Dan bahkan, tidak diketemukan hadits-hadits qauli tentang proses pelaksanaan ayat-ayat perkawinan beda agama tersebut. Hal ini memberi indikasi bahwa para sahabat dapat secara langsung memahami pesan-pesan naș sebelum kemudian mengamalkannya. Sehingga nyaris tidak diketemukan dialog antara mereka dengan nabi saw dalam rangka pemahaman muatan naș dimaksud.

\section{Perkawinan Lintas Agama dalam Perdebatan Sahabat.}

Perbedaan pendapat dalam Islam, khususnya masalah perkawinan lintas agama, sama sekali belum terjadi pada masa Rasul saw. Perbedaan pendapat terjadi sejak masa sahabat, yang kemudian terus berlanjut, bahkan sampai sekarang. Di antara beberapa sahabat yang pendapat dan perbuatannya berpengaruh pada sahabat-sahabat lain maupun generasi setelahnya (dalam masalah ini), dan banyak dikutip dalam kitab-kitab tafsir yang lahir berikutnya,

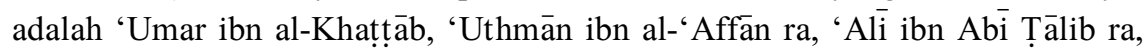
'Abdullāh ibn 'Abbās ra, 'Abdullāh ibn 'Umar ra, Jābir ibn 'Abdullāh ra, dan alHasan ibn 'Ali ra. $^{13}$ Namun dalam pembahasan ini penulis akan membaginya berdasarkan periode kekhalifahan.

Kendati terdapat empat khalifah sepeninggal Rasul yang menjadi penerus beliau, namun, dalam masalah perkawinan lintas agama, penulis sama sekali tidak menemukan satupun riwayat tentang pendapat maupun komentar khalifah pertama, Abū Bakr ra. Hal ini, sangat mungkin disebabkan oleh singkatnya masa pemerintahan beliau, yaitu hanya sekitar dua tahun. Beliau sangat disibukkan oleh gejolak politik Madinah dan beberapa pemberontakan di berbagai daerah. Di samping itu, beliau sangat terkenal sebagai sahabat yang

${ }^{12}$ Wael B. Hallaq menjelaskan bahwa, di Madinah nabi Muhammad saw melanjutkan peran dalam kapasitasnya (sebagai hakam), yang untuk beberapa waktu mendasarkan putusannya pada hukum adat dan praktek-praktek kesukuan yang berlaku. Di samping itu, dari penjelaskan al-Qur'ān dapat dilihat sesampainya di Madinah, beliau memikirkan misinya sebagai misi yang membawa hukum Tuhan seperti Taurat dan Injil. Lihat Wael B. Hallaq, A History of Islamic Legal Theories, 4.

${ }^{13}$ Terdapat 10 orang mufassir dari kalangan sahabat. Selengkapnya, lihat Muhammad ibn Muḥammad al-Adnarawìi, Ṭabaqāt al-Mufassirīn, Juz. I, Cet. I (Madinah al-Munawwarah: Maktabah al-'Ulūm wa al-Ḥikam, 1997), 3-7. 
gemar mencontoh nabi, padahal sebagaimana diketahui bahwa dalam hal ini, respon nabi juga tidak begitu tampak. Oleh karenanya, dapat diduga bahwa, dalam permasalahan ini, sikap Abū Bakr juga tidak jauh berbeda dengan sikap nabi saw.

Pada masa pemerintahan Umar ibn Khațāàb ra, paling tidak terdapat tiga hal penting berkenaan dengan perkawinan lintas agama: (1) perkawinan beberapa tentara Islam termasuk Jābir ibn Abdillāh ra dan Sa'd ibn Abī Waqqāṣ ra dengan wanita ahl al-kitāb setelah penaklukan kota Kufah, (2) perkawinan Hudhaifah ra saat menjadi gubernur di Madain dengan seorang wanita Yahudi, (3) beberapa perkawinan lintas agama yang diputus cerai oleh khalifah.

Dalam kasus pertama, Jābir ibn 'Abdillāh ra menjelaskan bahwa beberapa orang (termasuk dia dan Sa'd ibn Ab̄i Waqqāṣ) menikahi wanita ahl al-kitāb, karena (pada saat itu) mereka hampir tidak menemukan wanita muslimah. Namun ketika kembali ke Madinah, mereka menceraikan para wanita tersebut. Dan lebih lanjut ia menjelaskan bahwa wanita-wanita ahl al-kitāb halal bagi orang-orang Islam, namun tidak sebaliknya, para wanita muslimah tidaklah halal bagi laki-laki ahl al-kitäb. ${ }^{14}$

'Umar ibn al-Khattāb ra, yang pada saat itu menjabat sebagai pimpinan tertinggi umat Islam, tentunya mendapatkan berita tentang perkawinan tersebut. Namun, dalam hal ini tidak ditemukan satupun riwayat tentang pelarangan beliau berkenaan dengan perkawinan dimaksud. Hal ini berbeda dengan perkawinan yang dilakukan oleh Hudhaifah ra, di mana khalifah 'Umar ra begitu pro aktif turut campur di dalamnya. Bahkan, ia tampak memaksa Hudhaifah ra (gubernur Madain) agar segera menceraikan istrinya tersebut. ${ }^{15}$

Dalam hal ini, Khalifah 'Umar ra memberikan alasan yang sangat rasional, yakni, "kemaslahatan para wanita muslimah, juga keselamatan pejabat bawahannya". Apalagi sebagai orang terpandang, perbuatan Hudhaifah ra

\footnotetext{
${ }^{14}$ Lihat Abū Bakar Abd al-Razzāq ibn Hammām al-Șan‘ānī, Muṣannaf Abd alRazzāq, Juz. VII/178. Hadits tersebut juga dicantumkan al-Baihaqi dalam kitab Sunannya. Lihat Abū Bakr Aḥmad ibn al-Ḥusain ibn 'Alì ibn Mūsā al-Baihaqī, Sunan alBaihaqī al-Kubrā, Juz. VII/172.

${ }^{15} \mathrm{Di}$ antara riwayat tersebut menyebutkan bahwa, setelah Hudhaifah ra menikahi seorang wanita Yahudi, 'Umar ra mengirimkan surat kepadanya agar dia segera menceraikan istrinya tersebut (dalam suratnya) ia berkata: "Saya kuatir kalian akan meninggalkan para wanita muslimah, dan menikahi para wanita pelacur". Di dalam riwayat yang lain: "Hudhaifah membalas surat tersebut, dan ia berkata: "Apakah ia (wanita Yahudi) itu haram (dikawini)?", 'Umar ra menjawab: ”Tidak, akan tetapi aku khawatir kalian mengambil (jadi istri) para pelacur dari mereka. Lihat Abū Bakr Ahmad ibn al-Husain ibn 'Alīi ibn Mūsā al-Baihaqī, Sunan al-Baihaqū al-Kubrā, Juz. VII/173. Riwayat ini dikuatkan beberapa riwayat lain, termasuk apa yang di sampaikan oleh $\mathrm{Sa}$ ‘id ibn Manșūr dari jalur yang sama (Abū Wail). Lihat Sa‘ìd ibn Manșūr, Sunan Sa 'id ibn Manșūr, Juz. I, Cet. I (Riyāẹ: Dār al-‘Așìimi, 1414 H), 193.
} 
dikhawatirkan akan diikuti oleh masyarakat Islam yang dipimpinnya. Dan sebagai pimpinan tertinggi pada saat itu, 'Umar ibn al-Khatṭāb ra merasa sangat bertanggung jawab atas ketentraman umat Islam, sembari terus memantau kegiatan yang dilakukan oleh para pejabat (bawahannya)nya. Dengan demikian, dapat dikatakan bahwa teguran khalifah 'Umar ra terhadap Hudhaifah ra lebih bernuansa politis daripada religius (hukum agama). ${ }^{16}$

Dari dua kasus di atas, yakni perkawinan beberapa tentara Islam (pada saat penaklukan Kufah) dengan ahl al-kitäb, dan kasus perkawinan Hudhaifah ra dengan wanita Yahudi, Khalifah 'Umar ibn Khațāab ra menunjukkan sikap yang berbeda. Pada kasus pertama, sama sekali tidak diketemukan satu pun komentar beliau, sedangkan pada kasus perkawinan Hudhaifah ra terdapat beberapa riwayat yang menjelaskan ketidaksetujuannya atas perkawinan tersebut. Padahal kedua perkawinan tersebut sama-sama dengan ahl al-kitäb, hanya saja dilakukan dalam kondisi dan oleh pelaku yang berbeda.

Adapun perkawinan lintas agama yang diputus cerai oleh Umar ra adalah perkawinan antara wanita muslimah dengan lelaki ahl al-kitāb, baik mereka berbeda agama sejak sebelum menikah ataupun setelah menikah, yakni dengan masuk Islam atau murtadnya salah satu pasangan.

Dalam hal di atas, 'Umar ra tampak mengamalkan z̧āhir al-nașs (Q.S. 5: 5); bahwa lelaki muslim dapat mengawini wanita ahl al-kitāb, sedangkan wanita muslimah tidak dapat dinikahkan dengan lelaki ahl al-kitāb, kendati tidak ada ayat al-Qur'ān yang secara tegas melarang bentuk perkawinan tersebut. Di samping itu, beliau juga membatasi cakupan ahl al-kitäb, dengan tidak memasukkan Nasrani Arab dalam kategori tersebut, bahkan ia berjanji tidak akan membiarkan mereka, sampai mereka masuk Islam. ${ }^{17}$

Berbeda dengan Umar ra, 'Uthmān ibn al-'Affān ra menjadi salah satu pelaku perkawinan lintas agama. Hal ini terjadi pada tahun $28 \mathrm{H}$, beberapa tahun menjelang kewafatannya. Ia menikahi Nāilah bint al-Farāfiṣah, seorang wanita dari keluarga Nasrani, sebagaimana terekam dalam sebuah riwayat yang dibawa oleh 'Abdullāh ibn al-Sāib. ${ }^{18}$ Di dalam riwayat tersebut, terdapat

${ }^{16}$ Lihat Muhammad ibn Jarīi ibn Yazìd ibn Khālid Abū Ja'far al-Tabarī, Jāmi ${ }^{\circ}$ al-Bayān 'An Ta'wī Āyi al-Qur'ān, Juz. II/ 388. Pada masa berikutnya, Ibn Kathì juga mengutip riwayat tersebut, dan mengikuti pendapat al-Ṭabari yang menyatakan bahwa riwayat tersebut adalah yang paling sahịh. Lihat Ismā'il ibn 'Umar ibn Kathì Abu alFidā' al-Qurashī al-Dimashqì, Tafsìr al-Qur'ān al- 'Ażìm, Juz. I/347.

${ }^{17}$ Sikap tegas 'Umar ra ini terlihat dari pernyataannya, bahwa: "Orang-orang Naṣrani Arab bukanlah Ahl al-kitāb, dan tidaklah halal hewan-hewan sembelihan mereka. Akupun tidak akan membiarkan mereka, sehingga mereka masuk Islam, atau aku akan memukul leher (memerangi) mereka". Lihat Muhammad ibn Idris Abū 'Abdillāh al-

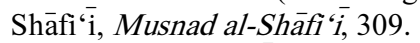

${ }^{18}$ Lihat Khalifah ibn Khiyāt Abū 'Umar al-Laithì al-'Ușfürì, Tärìkh Khalifah ibn Khiyāt, Juz. I/34. Pada umumnya riwayat tentang perkawinan 'Uthmān ibn al-'Affān ra 
indikasi bahwa Nāilah masih dalam keadaan Nasrani ketika dinikahi oleh 'Uthmān ra, kemudian ia masuk Islam. Namun data sejarah yang lain, sebagaimana dinyatakan oleh Ibn Kathīr dalam kitabnya, al-Bidāyah wa alNihāyah, menyatakan bahwa kendati Nāilah pada saat perkawinan masih dalam keadaan Nasrani, akan tetapi, ia telah masuk Islam sebelum dikumpuli oleh 'Uthmān ibn al-'Affān ra. ${ }^{19}$

Dengan demikian, 'Uthmān ibn al-'Affān ra tampak lebih longgar terhadap perkawinan lintas agama daripada Umar ibn Khattab ra, bahkan ia menjadi salah satu pelakunya.

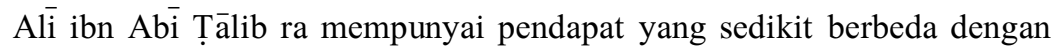
dua khalifah sebelumnya: Umar ibn Khatțab ra dan 'Uthmān ibn 'Affan ra. Ia tidak banyak membahas perihal perkawinan lintas agama. Beliau hanya melakukan penilaian terhadap orang-orang non muslim, khususnya Nasrani Arab yang banyak melakukan penyelewengan, sehingga mengeluarkan mereka dari identitas ahl al-kitāb. Dalam kaitannya dengan hal ini beliau menyatakan bahwa orang-orang Arab tidaklah beragama Nasrani, kecuali dengan meminum khamr. Oleh karena itu, beliau melarang umat Islam memakan daging hewan sembelihan mereka. ${ }^{20}$ Demikian juga dalam riwayat yang lain disebutkan

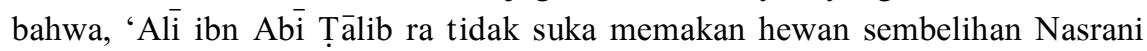
Arab maupun mengawini para wanita mereka. ${ }^{21}$

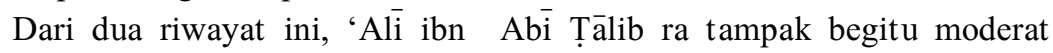
menyikapi non muslim, secara khusus ahl al-kitāb. Ia tidak serta merta melarang terjadinya perkawinan antara wanita mereka dengan lelaki muslim. Namun, dengan melihat kebusukan yang dilakukan orang-orang Nasrani Arab, ia kemudian menyatakan pendapat pribadinya untuk tidak memakan makanan yang mereka sembelih, begitu juga dengan menikahi para wanitanya.

dengan Nāilah bint al-Farāfiṣah al-Kalbiyah berakhir pada 'Abdullāh ibn al-Sāib dari keturunan (bani) al-Muțallib. Dalam hal ini ia menyatakan, bahwa 'Uthmān ibn al-'Affān ra, telah menikahi (Nailah) bint al-Farāfișah al-Kalbiyah, sedangkan ia adalah (satusatunya wanita) Nasrani di antara istri-istri 'Uthmān. Kemudian, ia masuk Islam di tangan 'Uthmān ibn al-"Affān ra". Lihat Abū Bakr Ahmad ibn al-Husain ibn 'Alì ibn Mūsā al-Baihaqi, Sunan al-Baihaqì al-Kubrā, Juz. VII/172. No. Hds. 13759.

${ }^{19}$ Selengkapnya, lihat Abu al-Fidā' Ismā'il ibn 'Umar ibn Kathīr al-Qurashì alDimashqī, al-Bidāyah wa al-Nihāyah, Juz. VII/163.

${ }^{20}$ Lihat: Abū Bakar Abd al-Razzāq ibn Hammām al-Șan'āni, Musannaf 'Abd alRazzāq, Juz. VII/186. Namun, berdasarkan ungkapan tersebut, 'Ațā' ibn Abì Rābah menganggap bahwa, 'Ali ra tidak memasukkan Nasrani Arab sebagai Ahl al-kitäb. Selengkapnya, lihat Abū Bakr Aḥmad ibn al-Ḥusain ibn 'Alì ibn Mūsā al-Baihaqié, Sunan al-Baihaqi al-Kubrā, Juz. VII/173.

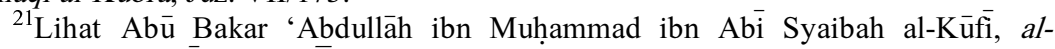

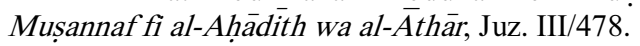


Setelah masa khalifah 4 berakhir, muncullah beberapa pendapat sahabat muda dalam kasus (perkawinan lintas agama) ini, yang kemudian dipegang oleh para pengikut mereka dengan segala perbedaan yang ada di dalamnya. Di antara mereka adalah, 'Ibn 'Umar ra, Ibn 'Abbās ra, dan al-Ḥasan ibn 'Alì ra.

Sikap 'Abdullāh ibn 'Umar ra (w. $74 \mathrm{H}$ ) tidak jauh berbeda dengan ayahnya, 'Umar ibn al-Khaț̣āb ra, di dalam menilai perkawinan lintas agama. Bahkan (dalam sebuah riwayat) ia tampak lebih serius menyatakan keharamannya dengan menganggap perbuatan ahl al-kitāb sebagai bentuk syirik

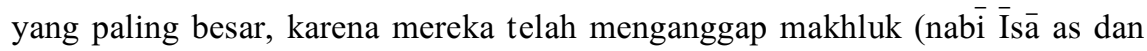
'Uzair as) sebagai tuhannya. Padahal menikahi wanita musyrik tidaklah diperbolehkan. ${ }^{22}$ Namun dalam riwayat lain, ia tidak langsung menyatakan bahwa perbuatan ahl al-kitäb adalah syirik yang terbesar. Kendati demikian, ia tetap pada pendiriannya, tidak menginginkan terjadinya perkawinan dengan ahl al-kitāb. ${ }^{23}$

Kendati sedikit berbeda, namun kedua riwayat tersebut sama-sama menafikan adanya perkawinan lintas agama, walaupun dengan ahl al-kitāb yang oleh mayoritas ulama diperbolehkan berdasarkan z̧āhir al-nașs Q.S. 5:5. Dalam hal ini, tidak terdapat banyak informasi tentang upaya 'Abdullāh ibn 'Umar ra di dalam mengkompromikan antara Q.S. 2: 221 dan Q.S. 5: 5, yang nampak bertentangan tersebut.

Hal ini berbeda dengan 'Abdullāh ibn 'Abbās ra (w. $70 \mathrm{H}$ ), yang lebih lunak di dalam menyikapi perkawinan mereka. Dalam kapasitasnya sebagai turjumān al-Qur'ān, yang secara langsung mendapat doa dari beliau saw, ${ }^{24} \mathrm{Ibn}$

${ }^{22} \mathrm{Di}$ antara riwayat tersebut dibawa oleh Imam Nāfi', sebagaimana diungkapkannya, bahwa Ibn 'Umar apabila ditanya tentang perkawinan (seorang muslim dengan) wanita Nasrani dan Yahudi, ia menjawab: "Sesungguhnya Allāh mengharamkan wanita-wanita musyrikat atas orang-orang mukmin, dan aku tidak mengetahui sutupun bentuk syirik yang lebih besar melebihi perkataan seorang wanita bahwa tuhannya adalah Isa (Nasrani), atau (ia berkata; tuhannya ialah) seorang hamba dari hamba-hamba Allāh (Uzair-Yahudi)". Lihat Muhammad ibn Ismā'ìl Abū Abdillāh al-Bukhārì al-Ju'fī, al-Jāmi ‘ al-Sahịh al-Mukhtașar, Juz. V/2024.

${ }^{23}$ Riwayat tersebut disampaikan Maimūn ibn Mihrān. Ia menyatakan bahwa 'Ibn 'Umar ra, membenci perkawinan wanita ahl al-kitāb (dengan lelaki muslim), dan beliau membaca ayat: "Dan janganlah kalian mengawini wanita-wanita musyrik, hingga mereka beriman". Lihat Abū Bakar 'Abdullāh ibn Muhammad ibn Abì Shaibah, al-Muṣannaf fi

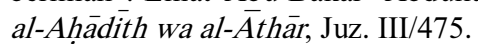

${ }^{24}$ Terdapat banyak riwayat tentang kekhususan doa Rasulullah saw terhadap 'Ibn 'Abbās ra tersebut, termasuk pernyataan Ibn 'Abbās ra sendiri yang dilansir muridnya, Sa'id ibn Jubair, bahwa Rasulullah saw menaruh tangannya di pundak Ibn "Abbās ra seraya berdoa: "Ya Allāh, berilah ia pengetahuan agama, dan ajarilah dia ta'wil". Lihat: Ahmad ibn Hanbal Abū Abdillāh al-Shaibānī, Musnad al-Imām Aḥmad ibn Hanbal, Juz. I/266. Bandingkan dengan: Muhammad ibn Hibbān ibn Ahmad Abū

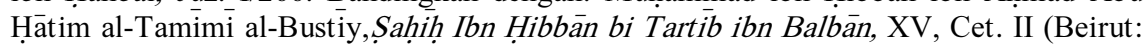
Muassasah al-Risālah, 1993), 531. 
'Abbās ra tidak terlalu banyak menggunakan ra'yu, melainkan materi al-Qur'ān sebagaimana dipahaminya. Sikap ini ditunjukkan Ibn 'Abbās ra ketika memberikan komentar tentang Nasrani Arab, yang menurutnya tidak ada masalah jika seorang muslim memakan hewan sembelihan mereka. ${ }^{25}$ Di samping itu, ia juga menjelaskan bahwa setelah Q.S. 2: 221 turun, para sahabat mencegah dari bentuk perkawinan tersebut. Maka setelah turun Q.S. 5: 5, mereka sama menikahi wanita ahl al-kitāb. ${ }^{26}$

Dalam riwayat tersebut, seolah Ibn 'Abbās ra memasukkan ahl al-kitāb dalam kategori musyrik. Hal ini dapat dilihat dari redaksinya yang berbunyi " $f a$ hajaza al-nās 'anhunna hattā nazalat al-latī ba'dahā'” Jika demikian, maka Q.S. 5: 5 berfungsi sebagai nāsikh, yang menyalin hukum ayat sebelumnya (Q.S. 2: 221), atau sebagai mustathnā yang mengecualikan dan membedakan ahl al-kitāb dari kelompok-kelompok musyrik lainnya. Dengan demikian dapat diduga bahwa Ibn 'Abbās ra lebih cenderung untuk menyatakan bolehnya mengawini wanita-wanita ahl al-kitāb dari kalangan manapun. ${ }^{27}$

Walaupun Ibn 'Abbās ra pada dasarnya membolehkan bentuk perkawinan di atas, namun ia juga tidak menafikan adanya pengaruh perkawinan itu pada si muslim. Sehingga, sangat disayangkan jika perkawinan tersebut mengakibatkan murtad atau goncangnya akidah si muslim. Oleh karena itu, di akhir pendapatnya, Ibn 'Abbās ra menyebutkan ayat wa man yatawallāhum minkum fainnahu minhum. ${ }^{28}$ Hal ini dapat dikatakan sebagai antisipasi bagi si muslim

${ }^{25}$ Sebagaimana riwayat yang dibawa Thaur ibn Zaid al-Dailamī, dan oleh alBaihaqi, dikutip dalam kitabnya. Dalam hal ini, Tsaur ibn Zaid, menyatakan: Dari Ibn 'Abbās ra, bahwasannya beliau (jika) ditanya tentang (boleh-tidaknya) memakan hewanhewan sembelihan para Nasrani Arab, maka beliau berkata: "Tidak apa-apa dengannya (yakni boleh memakannya), dan beliau membaca ayat: "wa man yatawallāhum minkum fa innahū minhum”. Lihat: Abū Bakr Aḥmad ibn al-Ḥusain ibn 'Alì ibn Mūsāa al-Baihaqī, Sunan al-Baihaqī al-Kubrā, Juz. IX/217.

${ }^{26} \mathrm{Komentar} \mathrm{Ibn}$ 'Abbās ra ini, terekam dalam sebuah riwayat yang disampaikan al-Tabrāni. Selengkapnya lihat: Abu al-Qāsim Sulaimān ibn Ahmad ibn Ayyūb alȚabrāni, al-Mu'jam al-Kabir, Juz. XII/105. Pendapat ini diikuti oleh beberapa tabi'i, termasuk: Mujāhid, Sa'ìd ibn Jubair, Ikrimah, dll. Lihat: Abu al-Fidā' Ismā'il ibn 'Umar

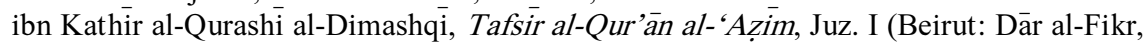
$1401 \mathrm{H}), 347$.

${ }^{27}$ Namun ia melarang perkawinan seorang muslim dengan wanita kafir harbi $\bar{i}$, walaupun ia seorang ahl al-kitāb. Lihat: Abd al-Raḥmān ibn 'Alīi ibn Muhammad al-

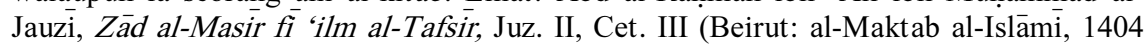
H), 297.

${ }^{28}$ Dalam hal ini lihat juga Mālik ibn Anas Abū 'Abdillāh al-Aṣbahī, Muwatta' al-

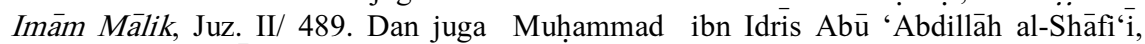
Musnad al-Shāfi ‘í, Juz: I/353. Riwayat ini dinilai lebih kuat daripada riwayat sebaliknya, yakni riwayat Ibn 'Abbās ra yang menyatakan tentang larangan Rasulullah saw perihal memakan sembelihan Nasrani Arab. Lihat Abū Bakr Ahmad ibn al-Husain ibn 'A $\overline{\bar{i}}$ ibn Mūsā al-Baihaqui, Sunan al-Baihaqū al-Kubrāa, Juz. 9/217. 
untuk mempertimbangkan perbuatannya sebelum menentukan pilihan; untuk menjalin hubungan perkawinan lintas agama (dengan wanita ahl al-kitāb).

Tokoh "sahabat muda" lainnya adalah al-Hasan ibn "Ali ra. Sebagaimana

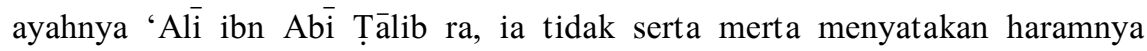
perkawinan antara seorang muslim dengan wanita ahl al-kitäb, namun mencoba untuk berfikir rasional dengan mengedepankan faktor "hājahkkebutuhan" dalam masalah perkawinan dimaksud. Pendapatnya yaitu bahwa perkawinan tersebut diperbolehkan jika dibutuhkan saja, namun jika tidak diperlukan lagi, maka hal itu tidak perlu dilakukan. Dan dengan semakin banyaknya jumlah wanita muslimah, menjadikan perkawinan antara seorang muslim dengan wanita ahl alkitāb bukan lagi suatu kebutuhan/ hajjah. ${ }^{29}$

Walaupun pada dasarnya, al-Ḥasan ra tidak mendukung perkawinan seorang muslim dengan wanita ahl al-kitāb, namun, beliau juga tidak menafikan akan munculnya suatu keadaan, di mana seorang muslim dihadapkan pada suatu pilihan sulit, yakni harus menikah dengan non muslimah: mungkin karena minimnya atau bahkan sama sekali tidak ada muslimah di daerah tersebut. Jika demikian halnya, beliau menyarankan agar dia mencari wanita ahl al-kitāa yang baik-baik.

Dari beberapa deskripsi di atas, dapat dikatakan bahwa pada masa sahabat telah terjadi perdebatan tentang boleh-tidaknya perkawinan antara orang Islam dengan non muslim. Namun, perlu diingat bahwa perdebatan tersebut masih terbatas pada satu masalah saja, yakni perkawinan lelaki Muslim dengan wanita ahl al-kitäb. Sedangkan, untuk wanita muslimah yang menikah dengan lelaki ahl al-kitāb, sama sekali tidak ada perbedaan pendapat di dalamnya, seakan mereka telah sepakat bahwa hal itu dilarang. Demikian juga wanita non muslimah, selain ahl al-kitāb (Yahudi-Nasrani), sama sekali tidak ada pendapat yang memperbolehkan perkawinan mereka dengan lelaki muslim, karena mereka diindikasikan sebagai al-mushrikāt, yang haram dinikahi (Q.S. 2:221).

${ }^{29}$ Dalam sebuah riwayat dari al-Hasan ibn 'Ali ra, dinyatakan bahwa ketika ia ditanya seorang lelaki: bolehkah dia (lelaki tersebut) menikahi wanita ahl al-kitäb? Hasanpun menjawab: "Ada masalah apa antara dia dan Ahl al-kitāb (padahal) Allāh telah memperbanyak (jumlah) wanita muslimah! Namun, jika ia harus melakukannya, hendaklah ia mencari wanita yang pandai menjaga diri (hișānan), bukan yang mudah berbuat keji (mufăhishah)? Orang tersebut berkata: Siapa "mufăhishah" itu?. Hasan menjawab: "Ia adalah wanita yang jika ada seorang lelaki bermain mata dengannya, ia meresponnya." Lihat Muhammad ibn Jarìi ibn Yazìd ibn Khālid Abū Ja'far al-Ṭabarí, Jāmi' al-Bayān 'An Ta'wì Āyi al-Qur'ān, Juz. IV/440. Pada generasi berikutnya, alSuyūți juga menyebutkan riwayat tersebut dalam tafsirnya al-Dürr al-Manthūr, dari jalur

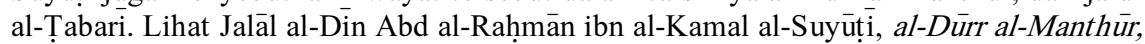
Juz. III (Beirut: Dār al-Fikr, 1993), 26. 
Dengan demikian, telah terjadi kesepakatan bahwa ahl al-kitāb adalah orang-orang Yahudi dan Nasrani. Akan tetapi, para sahabat masih berbeda pendapat dalam menentukan cakupan dan batasannya. Yakni, apakah istilah "Yahudi-Nasrani" tersebut hanya berhubungan dengan agama saja, ataukah juga berhubungan dengan keturunan/nasab pemeluknya, atau bahkan berhubungan dengan tempat awal pertumbuhan suatu risālah. Namun, ternyata perdebatan ini belum juga terselesaikan di masa mereka, dan pada akhirnya memunculkan perdebatan yang lebih luas pada masa-masa berikutnya. ${ }^{30}$

\section{Diskusi Tābi‘in perihal Perkawinan Lintas Agama.}

Transformasi keilmuan oleh para sahabat kepada generasi setelahnya merupakan titik tolak kemunculan para tābi‘īin, beserta keberagaman pemikiran mereka. Setidaknya terdapat 21 nama tābi ín yang mempunyai keahlian dalam bidang tafsir al-Qur'ān. ${ }^{31}$ Namun, dalam hal ini, penulis hanya akan memaparkan pendapat tiga orang tābi'īn (Mujāhid, Qatādah, dan 'Ațā') yang dianggap cukup untuk mereprentasikan perdebatan para generasi sebelumnya, serta menjadi pijakan bagi para tokoh generasi setelah mereka.

\section{a. Mujāhid ibn Jabr (w. $105 \mathrm{H})$}

Di antara pendapat Imam Mujāhid dalam kaitannya dengan perkawinan lintas agama sebagaimana diriwayatkan oleh beberapa muridnya ialah komentarnya berkaitan dengan penafsiran Q.S. 60: 10, terutama pada redaksi "wa lā tumsikū bi "ișām al-kawāfir." 22 Dalam hal ini, ia menjelaskan bahwa dengan turunnya ayat tersebut, para sahabat nabi diperintahkan untuk menceraikan istri-istri mereka yang masih kāfir, dan memilih tinggal bersama orang-orang kafir lainnya di Mekah.

Pada kesempatan lain ia juga mengomentari Q.S. 2: 221, tentang larangan mengawini wanita musyrikah. Dalam komentarnya tersebut, ia menjelaskan bahwa yang dimaksud dengan redaksi "al-kawāfir" dalam ayat tersebut adalah para wanita penduduk Mekah (yang masih musyrik). Namun,

\footnotetext{
${ }^{30}$ Perdebatan tersebut berlanjut ke masa tabi'i, tābi' al-tābi ‘īn, para tokoh salaf, bahkan sampai sekarang. Seperti perdebatan tiga tokoh mufassir pasca șahābat Mujāhid, Qatādah, dan 'Ațā'. Selengkapnya lihat Muhammad ibn Jarì ibn Yazid ib̉n Khālid Abū Ja'far al-Ṭabari, Jämi' al-Bayān 'An Ta'wìl Áyi al-Qur'ān, Juz. II/388. Lihat juga Abū Bakr Abd al-Razzāq ibn Hammam al-Șan'āní, Mușannaf Abd al-Razzāq, Juz. VII/176. Bandingkan dengan riwayat lain dalam kitab yang sama Abū Bakr Abd al-Razzāq ibn Hammam al-Ṣan‘āni, Muṣannaf Abd al Razzāq, Juz. VII/187.

${ }^{31}$ Selengkapnya, lihat Muhammad ibn Muhammad al-Adnarawi, Tabaqāt alMufassirin, Juz. I/9-18.

${ }^{32}$ Lihat Abū Bakr Aḥmad ibn al-Ḥusain ibn 'Alīi ibn Mūsā al-Baihaqìi, Sunan alBaihaqī al-Kubrā, Juz. VII/171.
} 
setelah itu turunlah Q.S. 5: 5 yang menghalalkan wanita-wanita ahl al-kitāb bagi orang Islām. ${ }^{33}$

Dari dua riwayat di atas, Mujāhid tampak lebih mengedepankan konteks ketika dua ayat tersebut turun, dengan mengatakan bahwa yang dimaksud dengan "al-kawäfir" pada Q.S. 60: 10 adalah wanita-wanita kafir (musyrikah) Mekah, demikian juga dengan "al-mushrikät” pada Q.S. 2: 221, yang tak lain adalah para wanita musyrik Mekah. Ia juga melanjutkan komentarnya tentang kebolehan menikahi ahl al-kitāb. Namun menurutnya, ahl al-kitāb masuk dalam kategori musyrik, yang kemudian dikecualikan untuk dapat dinikahi oleh orang Islam. Akan tetapi, ia sama sekali tidak menyinggung perihal kriteria, cakupan maupun batasan istilah tersebut.

Dengan demikian, kendati dalam penafsirannya, ia berangkat dari konteks sosial ketika ayat turun, namun menurutnya, khitāb dalam dua ayat tersebut bukan hanya untuk musyrik Arab saja, melainkan semuanya. Bahkan ahl al-kitāb pun masuk di dalamnya. Dan, dari semua kategori musyrik itu, ahl al-kitāb dikecualikan dalam hal perkawinan dan halalnya makanan antara mereka dengan umat Islam. Pendapat ini sejalan dengan pendapat beberapa tābi‘的 lain, seperti Ikrimah, Sa‘id ibn Jubair, Sa‘id ibn al-Musayyab, Hasan al-

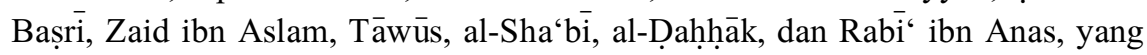
kesemuanya itu bermuara dari pendapatnya Ibn 'Abbās ra. ${ }^{34}$

\section{b. Qatādah ibn Da‘āmah (w. $117 \mathrm{H})$}

Qatādah memberikan pemisahan yang jelas antara musyrik dan ahl alkitāb, yakni bahwasannya musyrik adalah selain ahl al-kitāb. Hal ini berbeda dengan Mujāhid dan beberapa tābi ‘̄in lainnya yang memasukkan ahl al-kitāb dalam kategori musyrik, kemudian dikecualikan dalam hal perkawinan dan halalnya makanan bagi orang Islam, sebagaimana ditunjukkan Q.S. 5: 5. Perbedaan tersebut dapat kita cermati dari ungkapan Qatādah, yang menjelaskan pendapatnya di atas ketika menafsirkan Q.S. 2: $221 .^{35}$

\footnotetext{
${ }^{33}$ Lihat Abū Bakr Aḥmad ibn al-Ḥusain ibn 'Alì ibn Mūsā al-Baihaqī, Sunan alBaihaqī al-Kubrā, Juz. VII/171.

${ }^{34}$ Lihat Muhammad ibn Jarìr ibn Yazìd ibn Khālid Abū Ja'far al-Ṭabarì, Jāmi ‘ alBayān 'An Ta'wì Ayi al-Qur'ān, Juz. II/388. Lihat juga Abū Bakr Ahmad ibn al-Ḥusain ibn 'Alì ibn Mūsā al-Baihaqī, Sunan al-Baihaqu' al-Kubrā, Juz. VII/171. Bandingkan

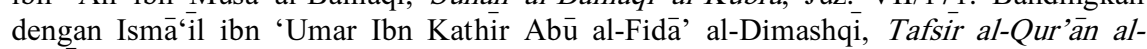
'Azịim, Juz. I/347. Juga dengan Abū 'Abdillāh Muḥammad ibn Aḥmad ibn Abū Bakr ibn Faraj al-Qurțūbì, al-Jāmi 'Li Aḥkām al-Qur'ān, Juz. III/64.

${ }^{35}$ Pendapat Qatādah ini dapat dilihat dalam sebuah riwayat yang dibawa alȘan'āni dari Ma'mar, ia menjelaskan bahwa ketika Qatādah menjelaskan Q.S. 2: 221, ia berkata: "Wanita-wanita musyrikāt adalah (non muslimah) selain Ahl al-kitāab".
} 
Walaupun dalam memahami Q.S. 2: 221, ia berangkat dari konteks sosial ketika ayat turun (yakni, kasus pada masa nabī), namun dalam penerapannya, ia memberlakukan ayat tersebut secara umum, seperti yang dilakukan oleh Mujāhid. Hal ini tergambar dalam ungkapannya bahwa al-mushrikāt, sebagaimana disebutkan dalam Q.S. 2: 221, adalah para wanita musyrikah Arab yang tidak mempunyai kitab (suci) untuk dibaca. ${ }^{36}$

Dengan demikian, Qatādah sekilas tampak menyempitkan makna musyrik dalam Q.S. 2: 221, yang hanya mencakup para penyembah berhala di Mekah (Arab). Namun, lebih lanjut ia menjelaskan bahwa, wanita-wanita selain ahl al-kitāb adalah mushrikāt. Ia juga memandang, kendati zăhir al-naṣs dalam redaksi Q.S. 2: 221 bersifat umum, namun ia diberlakukan secara khusus, sehingga tidak ada yang dinasakh sedikitpun. Dan menurutnya, para wanita ahl al-kitāb tidaklah masuk dalam cakupan ayat tersebut. ${ }^{37}$

Penjelasan di atas merupakan pendapat Qatādah berkenaan dengan kebolehan mengawini wanita ahl al-kitäb. Sedangkan dalam hal perkawinan lelaki muslim dengan wanita musyrikah, maupun lelaki ahl al-kitāb dengan wanita muslimah, Qatādah dengan tegas menolaknya. Ia menyatakan bahwa istri-istri musyrikah yang menolak untuk masuk Islam haruslah dicerai. Demikian juga, ia menekankan agar tidak ada seorang muslim yang mengawinkan para wanita muslimah dengan lelaki Yahudi, Nasrani, ataupun musyrik. $^{38}$

Dengan demikian, Qatādah telah menentukan posisinya dalam masalah ini dengan menyatakan kebolehan lelaki muslim mengawini wanita ahl al-kitāb,

Selengkapnya, lihat Abū Bakr Abd al-Razzāq ibn Hammām al-Ṣan‘ānī, Mușannaf Abd al-Razzāq, Juz. VII/176.

${ }^{36}$ Lihat Muhammad ibn Jarìr ibn Yazìd ibn Khālid Abū Ja'far al-Ṭabarì, Jāmi ‘ alBayān 'An Ta'wìl Àyi al-Qur'ān, Juz. II/388.

${ }^{37}$ Pendapat ini tergambar dalam riwayat yang disampaikan al-Ṭabari, yang mengutip pernyataan Qatadāh: "Bahwasannya maksud firman Allāh SWT wa lā tankiḥu al-mushrikāt hattā yu'minna, adalah siapa pun wanita (non muslim) selain ahl al-kitäb, masuk dalam kelompok "al-Mushrikāt". Dan ayat tersebut secara zāhir bersifat umum. Namun muatannya adalah khusus, tidak ada ayat lain yang menasakhnya, dan (yang pasti) wanita ahl al-kitāb tidaklah masuk dalam kategori tersebut". Setelah melakukan tarjih atas beberapa pendapat yang ada, al-Ṭabari menyatakan bahwa pendapat Qatadāh ini merupakan pendapat yang paling baik. Selengkapnya lihat Muhammad ibn Jarir ibn Yazìd ibn Khālid Abū Ja'far al-Ṭabarí, Jāmi' al-Bayān 'An Ta'wì $\bar{A} y i$ al-Qur'ān, Juz. II $/ 388$.

${ }^{38}$ Tentang haramnya mengawini wanita musyrikah, dapat dilihat pada penafsirannya atas Q.S. 60: 10. Sebagaimana riwayat Al-Ṭabari dari Qatadāh bahwa, para sahabat diperintahkan untuk menceraikan istri-istri mereka (wanita musyrikah Arab) yang menolak masuk Islam. Lihat Muhammad ibn Jarīi ibn Yazìid ibn Khālid Abū

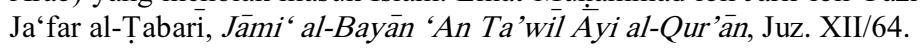


namun tidak sebaliknya, orang-orang non muslim tidak diperkenankan mengawini wanita muslimah.

\section{c. 'Ațā' ibn Abī Rabāh Aslam (w. 115 H)}

Jika dua tābi 'in di atas telah memisahkan antara musyrik dan ahl alkitäb, baik dengan istithna', maupun pemisahan dan pembedaan karakter keduanya. Maka, hal ini berbeda dengan pendapat 'Ațā, 39 yang mana menurutnya ahl al-kitāb itu merupakan sebutan khusus bagi para penganut Yahudi-Nasrani dari kalangan bani Israil saja, yang memang hanya kepada merekalah kedua kitab suci "Taurat dan Injil" diturunkan. Oleh sebab itu, ia tidak menganggap Nasrani Arab sebagai ahl al-kitāb, karena mereka bukanlah dari kalangan bani Israil. ${ }^{40}$

Pengambilan sikap tersebut membawanya pada sebuah konsekuensi bahwa lelaki muslim tidak diperkenankan menikahi wanita Nasrani Arab, demikian juga dengan memakan hewan sembelihan mereka. Pendapat ini semakin jelas, ketika ia menjawab pertanyaan yang diajukan oleh seorang muridnya, Ibn Juraij, perihal dimaksud. Dengan tegas ia menjawab bahwa, menurutnya, tidak ada istilah ahl al-kitāb selain hanya untuk bani Israil. ${ }^{41}$ Oleh karenanya, perkawinan lintas agama yang sah hanyalah jika dilakukan oleh

\footnotetext{
${ }^{39}$ Nama lengkapnya adalah 'Ațā, Abū Muhammad ibn Abī Rabah Maulā keluarga ibn Maisarah ibn Abi Khuthaim al-Fihrì. Nama ayahnya adalah Aslam. 'Atā tumbuh dewasa di Mekah. Ia adalah pengajar al-Qur'ān dan terkenal sebagai orang yang mendalam keilmuannya, terpercaya (thiqqah), dan banyak meriwayatkan hadits. Menurut Abū Ja'far; ia adalah orang yang paling tahu tentang manasik haji. Bahkan Abd alRahmān pernah berkata: "Imannya Abū Bakr tak tertandingi oleh penduduk bumi, sedangkan imannya 'Ațā tak tertandingi pula oleh ahli Mekah (saat itu)". Ia meninggal pada tahun $115 \mathrm{H}$, di usia 88 tahun. Pada saat itu, Maimun berkata: "Ia tidak tergantikan oleh generasi setelahnya". Lihat Muhammad ibn Sa'd ibn Mani' al-Hāshimi al-Bașrí, alTabaqāt al-Kubrā, Juz. VI/22. Lihat juga Muḥammad ibn Muhammad al-Adnarawi, Tabaqàt al-Mufassirin, 14.

${ }^{40}$ Pernyataanya tersebut terekam dengan jelas dalam riwayat yang disampaikan Abd al-Razzāq dari ibn Juraij. Dalam hal ini 'Ațā menyatakan: "Nasrani Arab bukanlah Ahl al-kitāb. Sesungguhnya ahl al-kitāb adalah bani Israil, yaitu orang-orang yang telah datang pada mereka kitab Taurāt dan Injil. Adapun orang-orang (selain bani Israil) yang masuk agama mereka bukanlah termasuk golongan mereka/Ahl al-kitäb." Lihat Abu Bakar Abd al-Razzāq ibn Hammām al-Șan'āni, Mușannaf Abd al-Razzāq, Juz. VII, Cet. III/187.

${ }^{41} \mathrm{Hal}$ ini dapat lihat pada riwayat Al-Ṣan'āni dari Ibn Juraij. Ia pernah bertanya kepada 'Ațā tentang orang-orang Nasrani Arab, dan tanpa ragu 'Ațā menjawab, bahwa umat Islam tidak boleh menikahi wanita-wanita mereka (Nasrani Arab). Lebih lanjut Ibn Juraij menjelaskan: "Ia ('Ațā) juga tidak menganggap orang Yahudi, kecuali hanya dari kalangan bani Israil. Dan apabila ia ditanya tentang orang-orang Nasrani, maka pasti demikianlah jawabannya (yakni hanya dari kalangan bani Israil)". Lihat Abū Bakar Abd al-Razzāq ibn Hammām al-Ṣan‘āni, Mușannaf Abd al-Razzāq, Juz. VI/72.
} 
lelaki muslim dengan wanita ahl al-kitāb (dari bani Israil), dan perkawinan tersebut juga akan menyebabkan "ịhsān" bagi para pelakunya. Maka jika mereka melakukan zina, yang pasti hukumannya adalah rajam. ${ }^{42}$

Dengan demikian, dapat diketahui bahwa perdebatan di kalangan tābi 'ín tidak jauh berbeda dengan apa terjadi pada sahabat, karena bagaimanapun pendapat para sahabat sangat berpengaruh pada generasi setelahnya terutama yang langsung bertemu dengan mereka (baca: tābi ‘َin). Dan perlu diketahui juga bahwa keberagaman pendapat sahabat banyak terjadi ketika mereka sudah tidak tinggal dalam satu komunitas lagi sebagaimana masa sebelumnya (saat Rasul masih hidup). Dan hal itu terjadi ketika mereka dihadapkan pada kasus, permasalahan, serta pertanyaan dari kaumnya, atau para tābi‘in di mana beberapa sahabat tersebut tinggal.

Perbedaan pendapat pada masa tābi ‘ंin (dalam masalah perkawinan lintas agama) tampak lebih beragam, dibandingkan perdebatan sahabat dalam kasus serupa. Namun, bagaimanapun, masih berakar pada pemahaman serta pengamalan zăhir al-nașs, karena permasalahan hanya berkutat pada perkawinan antara lelaki muslim dengan wanita ahl al-kitāb saja. Sedangkan masalahmasalah lain seperti: antara lelaki muslim dengan wanita musyrikah, atau antara wanita muslimah dengan lelaki non muslim sama sekali tidak diperdebatkan, seolah-olah mereka telah sepakat untuk menolaknya.

\section{Penutup}

Dari pemaparan di atas, dapat dicermati bahwa perbedaan pandangan mufassir sepeninggal Rasulullah saw, tentang perkawinan lintas agama banyak dipengaruhi oleh situasi dan motivasi pelaksanaan perkawinan dimaksud, kendati semuanya berangkat teks naș yang sama.

Pada masa tafsir formatif, perdebatan hanya terjadi dalam hal boleh tidaknya menikahi wanita $A h l$ al-kitäb, yang secara garis besar dapat dibedakan menjadi dua, yaitu: (1) Pendapat yang menyatakan bahwa wanita Ahl al-kitāb dapat dinikahi lelaki muslim berdasarkan zăhir al-nașs (Q.S. 5: 5). Pendapat ini dipegang mayoritas sahabat, seperti: 'Umar ibn al-Khațāa ra, 'Uthmān ibn

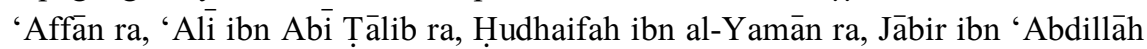

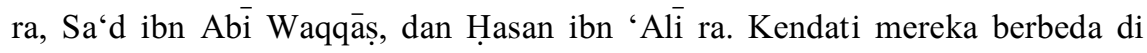
dalam menentukan kriteria, cakupan, serta batasan $A h l$ al-kitäb, namun mereka sepakat bahwa pada dasarnya lelaki muslim diperbolehkan mengawini wanita

${ }^{42}$ Lihat Abū Bakar Abd al-Razzāq ibn Hammam al-Ṣan‘ānì, Muṣannaf Abd alRazzāq, Juz. VII/308. Riwayat tersebut disampaikan 'Amr ibun Dīnār dari 'Ațā, tentang pernyataanya bahwa: "Menikahi wanita $A h l$ al-kitāb adalah ị̣sān (terjaga)". Dalam hal ini, al-Ṣan ‘āni juga menyebutkan riwayat yang sama namun dari jalur berbeda, yakni dari Ibn Juraij. 
Ahl al-kitāb (Yahudi dan Nasrani). (2) Kelompok yang berpendapat bahwa wanita Ahl al-kitāb tidak dapat dikawini seorang muslim, karena penyelewengan yang telah mereka lakukan masuk dalam kategori shirk, bahkan yang terbesar. Pendapat ini dilontarkan oleh 'Abdullāh ibn 'Umar ra, yang kemudian dipegang dan disebarkan oleh para muridnya. Sedangkan perkawinan antara lelaki muslim dengan wanita selain Ahl al-kitāb, ataupun wanita muslimah dengan lelaki non muslim, baik dari kalangan Ahl al-kitäb maupun yang lain, tidak satupun sahabat yang memperbolehkan.

Pada umumnya, secara konseptual, para mufassir dari kalangan tābi ${ }^{\bar{c}}$ in mengikuti pendapat pertama bahwa lelaki muslim boleh menikahi wanita non muslimah dari kalangan ahl al-kitāb (Yahudi-Nasrani), namun tidak sebaliknya, wanita muslimah tidak dapat dinikahkan dengan non muslim, kendati dari ahl al-kitāb sekalipun. Namun mereka (para tābi $\bar{i}$ in) mengembangkan diskusi tentang kreteria dan cakupun Ahl al-kitäb, sehingga memungkinkan terjadinya perluasan ataupun penyempitan definisi Ahl al-kitäb, yang dapat menyebabkan perubahan hukum tentang perkawinan lintas agama.

\section{Daftar Pustaka}

al-Adnarawī, Muhammad ibn Muḥammad. Tabaqāt al-Mufassirīn. Cet. I. Madinah al-Munawwarah: Maktabah al-'Ulūm wa al-Hikam, 1997 M.

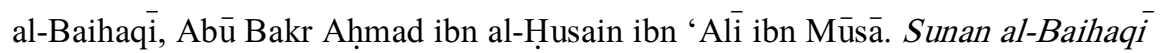
al-Kubrā. Makkah al-Mukarramah: Maktabah Dār al-Bāz, 1994 M.

al-Bașrī, Muhammad Ibn Sa‘d ibn Manī‘ al-Hāshimī. Al-Ṭabaqāt al-Kubrā. Cet.

II. Beirut: Dār al-Kutub al-'Ilmiyah, 1997 M.

al-Bukhārī, Muhammad ibn Ismā'īil Abū 'Abdillāh al-Ju'fì. Al-Jāmi' al-Sahịh alMukhtașar. Cet. III. Beirut: Dār Ibn Kathīr al-Yamāmah, 1987 M.

Hallaq, Wael B. The Origins and Evolution of Islämic Law. Cet. I. Cambridge: Cambridge University Press, $2005 \mathrm{M}$.

. A History of Islamic Legal Theories, an introduction to sunni usūul al fiqh. Cambridge: Cambridge University Press, 1997 M.

Ibn Hibbān ibn Aḥmad Abū Hātim al-Tamīmī. Sahịh Ibn Hibbān bi Tartīb ibn Balbān. Cet. II. Beirut: Muassasah al-Risālah, 1993 M.

Ibn Kathīr al-Qurashī. Tafsìir al-Qur'ān al-'Azīim. Beirut: Dār al-Fikr, 1401 H.

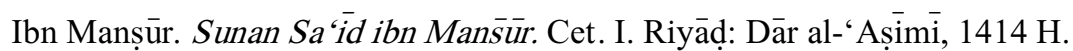

Mālik ibn Anas Abū 'Abdillāh. Muwatta'a' al-Imām Mālik. Muhaqqiq: Taqī alDin al-Nadwì. Cet. I. Damascus: Dār al-Qalam, 1991 M. 
al-Nasā', '̇, Ahmad ibn Shu'aib Abū Abd al-Raḥmān. Al-Mujtabā min al-Sunan. Muhaqqiq: Abd al-Fattāh Abū al-Ghadah. Cet. II. Halb: Maktabah alMaṭbū'àt al-Islāmiyah, 1986 M.

al-Qurțūbi, Abū 'Abdillāh Muḥammad ibn Aḥmad ibn Abū Bakr ibn Faraj. AlJāmi ' Li Aḥkām al-Qur’ān. Cet. II. Kairo: Dār al-Shu'ūb, 1372 H.

al-Shāfi ‘⿳亠丷, Muhammad ibn Idrīs Abū 'Abdillāh. Musnad al-Shāfi ‘ $\bar{i}$. Beirūt: Dār al-Kutub, tt.

al-Sijistānī, Sulaimān ibn al-Ash'ath Abū Dāwūd. Sunan Abī Dāwūd. Muḥaqqiq: M. Muhȳi al-Dīn Abd al-Ḥamīid. Beirut: Dār al-Fikr, tt.

al-Suyūțí, Jalāl al-Dīn Abd al-Raḥmān ibn al-Kamal. Al-Dūrr al-Manthūr. Beirut: Dār al-Fikr, 1993 M.

al-Ṭabarī, Muhammad ibn Jarīi ibn Yazīd ibn Khālid Abū Ja'far. Jāmi' al-Bayān 'An Ta'wìl Á yi al-Qur'ān. Beirut: Dār al-Fikr, 1405 H.

Tärikh al-Umam wa al-Mulūk. Cet. I. Beirut: Dār al-Kutub al-Ilmiyyah, $1407 \mathrm{H}$.

al-Ṭabrānī, Abū al-Qāsim Sulaimān ibn Aḥmad ibn Ayyūb. Al-Mu'jam alKabīir. Cet. II. Mūṣal: Maktabah al-'Ulūm wa al-Ḥikam, 1983 M.

Thameem, Ushama. Methodologhies of the Qur'anic Exegesis. Kuala Lumpur:

A.S. Noordeen, $1995 \mathrm{M}$.

al-Turmudhì, Muhammad ibn 'Īsā Abū 'İsā al-Sulamī. Al-Jāmi' al-Sahị̂h Sunan al-Turmudhì. Beirut: Ihȳā al-Turāth al-'Arabī, tt.

al-'Umarī, Akram Diyā'. Madinah Society at the time of the Prophet. Translated from al-Mujtama' al-Madāni fí al-Nubuwwah by Huda Khattāāb. Edisi. II. Virginia: the International Institute of Islam ic Thought, $1995 \mathrm{M}$.

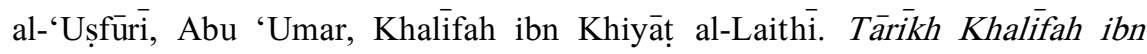
Khiyāt. Cet. II. Beirut: Dār al-Qalam, 1397 H.

al-Zarqānī, Muhammad 'Abd al-'Azīim. Manāhil al-'Irfān fī 'Ulūm al-Qur'ān. Beirut: Dār al-Kitab al-`Ilmi, 1996 M. 